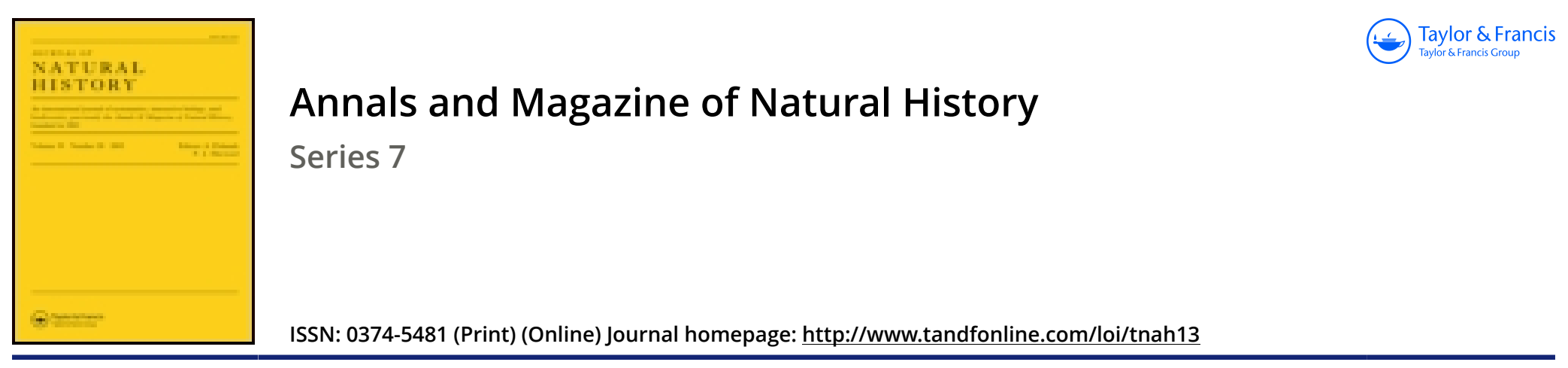

\title{
LXIII._Lamellicorn Coleoptera from the Nilgiri Hills
}

\section{Sharp M.A. M.B. F.R.S.}

To cite this article: D. Sharp M.A. M.B. F.R.S. (1903) LXIII._Lamellicorn Coleoptera from the Nilgiri Hills, Annals and Magazine of Natural History, 11:65, 467-473, DOI: $10.1080 / 00222930308678800$

To link to this article: http://dx.doi.org/10.1080/00222930308678800

册 Published online: 29 Sep 2009.

Submit your article to this journal $\sqsubset \pi$

Џ Article views: 3

Q View related articles $\sqsubset$

Citing articles: 1 View citing articles $\square$ 


\section{LXIII.-Lamellicorn Coleoptera from the Nilgiri Hills. By D. Sharp, M.A., M.B., F.R.S., \&c.}

Four'teen species of Phytophagous Lamellicorn Coleoptera were recently sent by $\mathrm{Mr}$. C. A. Barber (Government Botanist at Ootacamund, S. India) to the Cambridge Museum to be named. On studying them it appeared that names could not be found for nine of the species, and I here give descriptions of seven of them. Of the other two species only single examples were sent, and they remain to be dealt with when more material shall have been received. A complete set of the new species has been placed in the British Museum (Natural History) and also one in the Museum of the University at Cambridge.

\section{Holotrichia repetita, sp. n.}

Elongata, testacea, plus minusve picescens, parce punctata; supra nitida, subtus pectore sat dense villoso; capite ecarinato, dense fortiter punctato, clypeo fere rotundato; thorace brevi, parce punctato; elytris fortiter et irregulariter punctatis, subcostatis, utrinque ad basin impressis, impressione oblique strigulosa.

Long. 18-20 $\mathrm{mm}$.

This species has quite the aspect of a somewhat long and narrow Rhizotrogus. The clypeus is slightly emarginate in the middle and the whole of the apper surface of the head is coarsely subrugosely punctate. The thorax is very short, the hind angles are definite and obtuse, not at all rounded, the lateral margin is very fine, its front half is very obscurely crenate, there is no expansion, or at most a very slight one, at the front angles; the punctuation is rather distant and coarse, the surface quite shining. Scutellum broad, coarsely punctate. Elytra coarsely and irregularly punctured, elevated along the suture, and each with four other longitudinal elevations - the one next the suture diverges from it in front and disappears before reaching the base; the second is parallel with the first, and between the two at the base there is a depression which is always crossed by two or three fine ruga; the third elevation is much shorter, and the fourth is a slender one parallel with the outer margin. Pygidium rather small, densely punctate, not convex. Legs long and slender. Labrum deeply divided, its lobes subtruncate. Mentum with only four or five setæ on each side in front. Antennæ 10-jointed, the club about as long as joints 2-7. I am not sure whether all the specimens before me are males or 
not; if the female is among them it is extremely like the male externally.

May be placed early in the genus, near $H$. parallela. The collection in the British Museum includes a very old specimen labelled "montana, Reiche, Ghauts," which I believe is this species.

Ootacamund (C.A. Barber, no. 202 a). In the collections of the Cambridge Museum, British Museum, and D. Sharp.

\section{Holotrichia conferta, sp. n.}

Testacea, plus minusve piceo-sbscurata, densissime punctata, opaca, pectore densius villoso; vertice alte carinato, carina emarginata; clypeo brevissimo, dense punctato, medio emarginato; elytris ecostatis.

Long. 16-18 $\mathrm{mm}$.

Mentum in front on each side with a series of long appressed golden hairs covering its surface. Labrum very deeply emarginate. Antennæ 9-jointed, joints 3 and 4 rather short, sharply divided. Clypeus very short and broad, greatly reflexed in front, and broadly but not deeply emarginate. Vertex elevated to form a very strong carina, slightly notched in the middle. Thorax with the hind angles extremely obtuse, the side margin explanate at the front angles, the anterior margin thick, sharply elevated, so as to have a perpendicular face, adapted to the carina of the vertex; the whole surface extremely densely punctate. Scutellum not covered by the hair of the thorax, punctate. Elytra very densely punctate, with a longitudinal impression near the suture, abbreviated in front, and limiting a broad, more coarsely and less densely punctate space. Pygidium broad, rather feebly punctate. Abdominal sutures less effaced than usual. Breast densely clothed with tawny pubescence. Club of antenna short in the female, moderately long in the male.

This may be placed near $H$. sinensis. There is a very old specimen in the British Museum labelled "Madras."

Ootacamund (C.A. Barber, no. 202b). In the collections of the Cambridge Museum, British Museum, and D. Sharp.

\section{MelaseriCa, Brenske.}

Melaserica, Brensike, Berlin. ent. Zeitschr. xlii. 1897, p. 421.

'This genus has been recently characterized by Herr Brenske and is based on two male specimens found in Tibet at Tatsien-lu. Brenske's description is necessarily very brief, and 
there is consequently some doubt whether a large Serica found by Mr. Barber in the Nilgiri Hills really belongs to it. It possesses, however, the chief character of Melaserica, viz. that in the male the club of the antenna has five leaflets. In the Nilgiri species there are really five leaflets in the male, and, in addition, a considerable prolongation of the fifth joint. In the female of $M$. Barberi there are only four leaflets in the club. The eyes in $M$. Brenskei are remarkably large, and as they are small in $M$. thibetana, and as the specific characters of the two are very different, it must remain doubtful whether the two forms are really congeneric.

\section{Melaserica? Barberi, sp. n.}

Suboblonga, valde convexa, rufescens, supra (præsertim anterius) late nigricans; obsolete punctata, elytris leviter striatis. Long. $11 \mathrm{~mm}$.

Clypeus red, vertex black, the former shining and coarsely punctate, the latter dull and impunctate, so that the two parts are very different. Eyes large and convex. Thorax short, narrowed in front, the side very little rounded, the hind angles nearly rectangular, only prevented from being so by a short obliquity or change of direction in the base close to them; the surface broadly black, redder about the sides, very dull, almost impunctate. Scutellum elongate, obsoletely punctate. Elytra about the base and suture black, feebly striate, with the interstices slightly convex; dull and almost destitute of punctuation. Pygidium large, black, marked with red along the middle and at the sides. Under surface red, very dull; middle coxæ but little separated; lower face of hind femur dull and impunctate.

The female agrees rather closely with the male except in the structure of the antennæ and in the eyes being a little smaller.

Ootacamund (C.A. Barber, no. 210); Nilgiri Hills (Sir G. F. Hampson, 94-89, Brit. Mus. Coll.). In the collections of the Cambridge Museum, British Museum, and D. Sharp.

\section{Serica nilgirensis, sp. $\mathrm{n}$.}

Affinis S. indicce, Bl. Suboblonga, rufescens, supra vix opalescens ; elytris crebre irregulariter punctatis, leviter striatis, interstitiis subconvexis.

Long. $7-7 \frac{1}{2} \mathrm{~mm}$.

Differs in numerous details from $S$. indica, to which it is closely allied. Male club of antenna very elongate, twice as 
long as the scape, in the female not half as long. Clypeus small, very coarsely punctate, similar in the two sexes, very slightly concave in the middle; front plate of mentum strongly transverse, almost oblong. Head and thorax sometimes red, sometimes infuscate, sparingly though not finely (on the disk of the thorax obsoletely) punctate; hind angles strongly rounded. Scutellum elongate, very coarsely punctate, with an indefinite smooth space along the middle. Elytra with a coarse subrugulose sculpture, and each with eight longitudinal shallow grooves; on the interstices the sculpture is less concentrated than it is in the grooves, where, indeed, it is concentrated and irregular; the setæ are excessively minute and scanty, though this evidently depends to some extent on attrition. Pygidium obsoletely punctate. Metasternum elongate in the middle, its lateral wings not much more than half as long as the hind coxæ; these are very densely coarsely punctate. Hind femora nearly smooth below, their lower hind margin nearly straight, their upper hind margin very strongly curved, and projecting, near the base, farther back than the lower margin. Tarsi very long and shining.

Ootacamund (C. A. Barber, no. 207); apparently abundant. In the collections of the British Museum, Cambridge Museum, and D. Sharp.

The species shows numerous differences from that determined ( $I$ believe correctly) in the British Museum as S. indica, Blanch.

\section{Serica pilula, sp. n.}

Rotundato-ovalis, convexa, nigra, opaca, obsolete punctata; elytris obsolete striatis; antennis rufo-sordidis, tarsis piceo-rufis. Long. $5-6 \mathrm{~mm}$.

This is a peculiar species, that becomes very compact and subspherical in form when contracted. This, with the comparatively small eyes and the condition of the specimens, seems to indicate very subterranean habits. Antennæ 10-jointed, the sixth and seventh joints extremely short; the club rather long, longer than the scape. Clypeus small, cmarginate in front. Front of mentum smooth and shining, rather large, depressed, its lower margin strongly curved. The sculpture of the whole of the surface peculiarly effaced, the surface dull; the striation of the elytra very fine, indistinct. Middle coxæ widely separated; metasternum short in the middle, almost without channel. Hind cosæ not large, sparingly punctate. Abdomen short; pygidium short. 
This species did not exist in the British Museum collection.

Ootacamund (C.A. Barber, no. 214); apparently rare. In the collections of the British Museum, Cambridge Museum, and D. Sharp.

\section{Anomala Olivieri, sp. n.}

A. variantis, Ol., affinis, sed superne picea vel nigricans. Long. 20-21 mm.

Melolontha varians, var. $b$, Olivier, Ent. i. 5, p. 8, pl. x. fig. 123 b.

This species has been long known, and was in fact treated by Olivier as a variety of $A$. varians when he first characterized that species. It is apparently distinct, no intermediates having been discovered. The series forwarded by Mr. Barber exhibits a little variation in colour. The sides of the thorax are sometimes extensively pallid, and the dark colour has a variable degree of extension on the pygidium. The legs and under surface of the three thoracic divisions are pallid, the tarsi and ventral segments piceous, and the dark colour extends more or less on to the middle of the metasternum ; the terminal ventral plate and the hind margin of the penultimate one are dirty yellow, the broad intervening membrane being more pallid.

The male and female are very much alike, but the male has the hind femora punctate and covered with long pubescence over the whole of the lower face, while in the fernale there is a smooth space along the middle, limited posteriorly by a series of bristles, behind which the surface is coarsely sculptured and somewhat pubescent. There are also slight differences in the club of the antenna, in the clypeus, in the shape of the claws and the length of the legs, as well as in the shape of the pygidium. In the series before me the female is very much rarer than the male.

In the collections of the Cambridge Museum, the British Museum, and D. Sharp.

Ootacamund (C.A.Barber, no. 201).

\section{Anomala globulosa, sp. n.}

Brevis, convexa, nigricans; antennis, palpis tarsisque testaceis ; corpore subtus parce testaceo-hirsuto; elytris punctato-sulcatis. Long. 6-7 mm.

This little species is not at all allied to any other and has the appearance of a minute Dynastid rather than of a Rutelid. 
It may be compared with $A$. ignicollis, which is as much like it as any other species I know. I have only males before me.

The club of the antenna is remarkably long, being equal to the width separating the eyes. The head is small, the clypeus very much rounded, strongly margined; the surface of the head coarsely irregularly punctured, uneven and rugose. Thorax black and shining, sparingly punctate, the basal margin obsolete except near the angles. Scutellum only very finely punctured. Elytra with deep but irregular striæ, which are coarsely and irregularly punctured. Pygidium rather large, elongate and vertical, not convex, coarsely rather sparsely punctate, shining. Legs short; hind femora very broad. Claws unequal, those on the anterior feet quite short, the anterior of the two thick, and with a very short division, which is scarcely separated from the body of the claw; on the other feet the claw is not divided. The abdomen is very short.

Ootacamund (C.A. Barber, no. 213); apparently rare. In the collections of the British Museum and the Cambridge Museum.

The elytra are obscure reddish in one of the British Museum examples.

\section{Adoretus ovalis, Blanchard.}

Fusco-niger, antennis testaceis, pedibus rufo-sordidis; tenuiter breviterque pallide setosus, nullo modo squamosus ; elytris obsolete tricostatis.

Long. $12-13 \mathrm{~mm}$.

One of the most obscure species of the genus, destitute of any salient character, and with only a slight difference between the sexes. Mr. G. J. Arrow considers the specimens here described to be $A$. ovalis, Blanch. (Cat. Coll. Ent. p. 233), and as there is nothing in Blanchard's brief description to contradict this, and as the locality agrees, this determination may be accepted, though $I$ at first thought that the species was undescribed.

Upper surface somewhat shining, rather finely and indefinitely subrugosely punctate, clothed with scanty, short, pallid, adpressed hairs, none of which are at all like scales. Clypeus rather narrow, eyes only moderately large. Thorax short, in the male a little, in the female strongly narrowed in front; basal margin fine, distinctly sinuate on each side of the middle. Elytra with a scarcely perceptible metallic shimmer and each with three very fine and faint costæ. 
Under surface sparingly setose, the hairs longer than on the upper surface. 'The chief distinction between the sexes is that in the female the pygidium is extremely short; in the male it is twice as long.

Ootacamund (C.A.Barber, no. 205). In the collections of the British Museum, Cambridge Museum, and D. Sharp.

Cambridge,

March, 1903.

\section{LXIV.-On a new Rat of the Mus rufescens Group from Simla. By J. Lew is Bonhote, M.A.}

WHEN revising the Oriental rats of the Mus rattus group a short time ago I came across a series of eleven from Simla, differing, so far as I know, from the numerous rats of this group which have already been described. I therefore propose to describe it under the name

Mus vicerex, sp. $\mathrm{n}$.

Similar in size to typical Mus rufescens, but with shorter tail.

General colour yellowish grey, lighter on the flanks and darker on back, interspersed with long black hairs which, when seen in certain lights, have a greenish gloss. Underparts and feet white, the facial portion and top of the nose very grey. Tail of medium length, not exceeding that of the head and body, markedly bicolor and well clothed with numerous very fine hairs. Ears large and uniform dark brown in colour, having a very narrow line of white hairs round the extreme margin. Fur thickly beset with long and slender spines.

The skull resembles that of $M$. rufescens very closely; it differs, however, in the greater breadth of the nasals, with which is correlated a stouter muzzle. The audital bullæ are rather less inflated on their outer surface, giving them the appearance of lying more obliquely on the skull.

Dimensions (of type) from dried skin :-Head and body 173 millim. ; tail (tip broken) 130 ; hind foot 33 ; ear 23.

Skull: greatest length 42 millim.; basal length 34 ; palatal length 20 ; length of nasals 15 ; breadth of nasals anteriorly 4.5 ; greatest breadth of muzzle 7 ; zygomatic breadth, approx., 21 ; greatest breadth of brain-case 16.

$H a b$. Simla. 